DOI: $10.1355 / \mathrm{ae} 26-1 \mathrm{~d}$

\title{
Banking and Financial Sector Reforms in Vietnam
}

\author{
Suiwah Leung
}

\begin{abstract}
This paper summarizes Vietnam's developments in the banking and financial sector to date. It assesses the system's weaknesses that played an important role during the macroeconomic turbulence of 2008. It then discusses the need for deeper reforms of the country's key macroeconomic institutions. In general, for Vietnam to achieve its goal of becoming a modern industrialized economy by 2020, it needs to have world-class public institutions to complement a flexible and entrepreneurial private sector. Nowhere is this more true than in the banking and financial markets where effective policy-making and skilful regulation have to be balanced against profitable risk-taking — all set against a background of commitment to a one-party state where social and political stability still reigns supreme.
\end{abstract}

Keywords: Finance, banking, institutional reforms, macroeconomic turbulence, prudential supervision.

\section{Introduction}

Vietnam has made significant progress in socioeconomic development since Doi Moi some twenty years ago, and is well on the way to become a middle-income country. This was achieved essentially through two phases of economic reforms: Doi Moi 1 (1986-1996), and Doi Moi 2 (2001-2007). The success of Doi Moi 1 in opening the economy to international trade and investment has been amply documented (see, for example, Dollar and Litvack 1998; Leung and Thanh 1996; Riedel 1999). However, the trade and investment regime throughout the 1990s was so tilted towards the state sector that the prospects for continued growth were limited. Almost all the foreign direct investment (FDI) at the time went into joint ventures with the state-owned enterprises where both productivity and profitability were low. It was not surprising that the inflow of FDI began dwindling as early as 1996, well before the onset of the Asian financial crisis in mid-1997 (see Figure 1 below, and Leung forthcoming). Since the new millennium, Doi Moi 2 began "unleashing" the domestic private sector and addressed the discrimination inherent in the trade and investment regime, starting with the Enterprises law in 2000, the Unified Enterprises Law in 2005, the Vietnam-U.S. bilateral trade agreement in 2006, and culminating in the muchdiscussed Vietnam's entry into the WTO in 2007. This second phase of reforms resulted in rates of economic growth second only to that of China's, fuelled by FDI and remittances, this time linking Vietnam's domestic private sector to the vibrant 
production network of the Asian region, and fast closing the development gap between Vietnam and its original ASEAN neighbours (Bingham and Leung forthcoming).

At the same time, research shows that, compared with low-income developing countries on the one hand, and high-income developed countries on the other, middle-income emerging market economies are the most vulnerable to financial crises and instability — the 2008 credit crisis in the United States notwithstanding (Reinhart and Reinhart 2008). This paper therefore assesses Vietnam's developments in the banking and financial sector to date, and focuses on deeper institutional reforms in the future. In general, for Vietnam to realize its goal of becoming a modern industrialized economy by 2020 , it needs to have world-class public institutions to complement a flexible and entrepreneurial private sector. Nowhere is this more true than in the banking and financial markets where effective policy-making and skilful regulation have to be balanced against profitable risk-taking, all set against a background of commitment to a one-party state where social and political stability still reigns supreme.

This paper is structured as follows. Section II gives a brief summary of the recent financial sector developments and an assessment of the unresolved problems. Section III discusses the asset price bubble and macroeconomic instability of mid-2008, and the extent to which these were directly and indirectly related to the unresolved problems in the financial sector. Section IV points out the need for continued deep institutional reforms in order to take advantage of financial globalization whilst minimizing the risks of financial crises. The concluding section addresses the balance of interests in contemporary Vietnamese society which could affect the likelihood of such reforms being adopted.

FIGURE 1

FDI Inflow to Vietnam (as percentage of GDP)

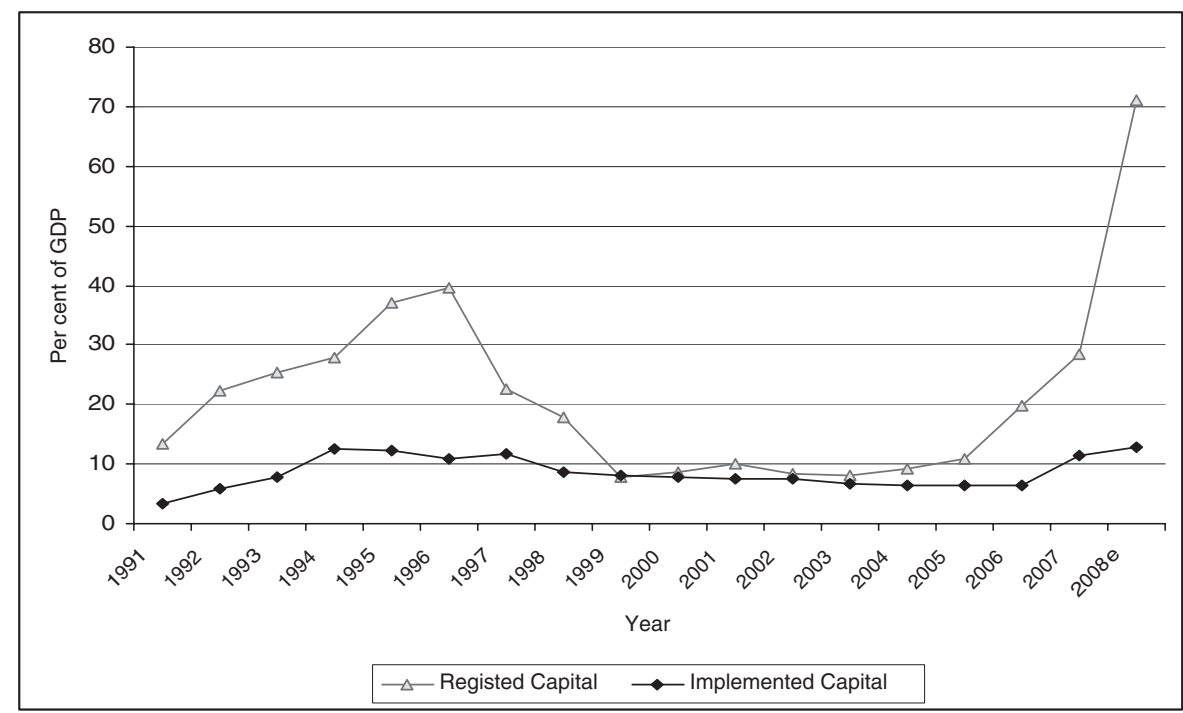

SourCES: 1991-2007 FDI inflow data from GSO, Available at <http://www.gso.gov.vn>, Accessed date: 28 December 2008.

Estimated data for 2008 are from Reuter: <http://www.fxstreet.com/news/forex-news/article.aspx?StoryId=7609b5c11012-4599-b075-59b3e903281b>. 


\section{Recent Financial Sector Developments}

The various steps in the liberalization and reform of Vietnam's formal financial sector as the country moved from plan to market have been documented and analysed in the literature (World Bank 2002; Kovsted et al. 2005; IFC 2007, 2008). Without a doubt, the most significant steps include the deregulation of domestic interest rates (on both dong and foreign currency deposits and loans) during the period 1996-2002, the decision in May 2005 to restructure the state-owned commercial banks (SOCBs) and have them equitized by 2010 , and of course the recent decision to permit 100 per cent foreign-owned banks to enter the market as per commitment to WTO. Meanwhile, the exchange rate is still administered and exchange controls remain in place. Rather than reviewing the history of these reforms, this section highlights certain recent developments in the Vietnamese financial sector that are pertinent for macro- economic stability and for the continued growth and development of its economy.

Table 1 shows that formal financial markets in Vietnam both grew and diversified rapidly in recent years. Bank deposits as a percentage of GDP grew quickly from 60 per cent in 2004 to 99 per cent in 2007 before falling back to 92 per cent in 2008, reflecting monetary deepening in the economy in the medium term, but also short-term financial turbulence towards the latter half of 2007 (see section III below). Share market capitalization also grew from about 6 per cent of GDP in 2005 to 15 per cent in 2008. Signs of a share market bubble are certainly evident in 2006 and 2007 when capitalization peaked at 43 per cent of GDP before falling back to 15 per cent towards end-2008. Bonds (especially private sector corporate bonds), insurance and pension funds became established in the new millennium, but have remained relatively small.

TABLE 1

Financial Markets in Vietnam

(Percentage of GDP)

\begin{tabular}{lccccccc}
\hline & 2002 & 2003 & 2004 & 2005 & 2006 & 2007 & $2008^{f}$ \\
\hline Deposits as \% of GDP $^{\mathrm{a}}$ & 48 & 52 & 60 & 67 & 78 & 99 & 92 \\
Loans as \% of GDP $^{\mathrm{a}}$ & 45 & 52 & 61 & 70 & 75 & 93 & 93 \\
Share market (total capitalization) $^{\mathrm{b}}$ & 0.96 & 2.06 & 3.50 & 5.55 & 22.61 & 43.38 & 15 \\
Outstanding bonds as percentage of GDP $^{\mathrm{c}}$ & $\mathrm{NA}$ & 7.3 & 8.4 & 8.2 & 8.1 & 13.7 & 15.1 \\
Insurance premium (both life and non-life) $^{\mathrm{d}}$ & 1.44 & 1.72 & 2.00 & 1.63 & 1.54 & 1.44 & NA \\
Pension funds $^{\mathrm{e}}$ & 3.45 & 3.59 & 4.12 & 4.04 & 3.70 & NA & NA \\
\hline
\end{tabular}

Source: a. World Bank, Vietnam Development Report 2009: Capital Matters, World Bank Report to the Vietnam Consultative Group Meeting, Hanoi, December 4-5, 2008.

b. State Security Commission.

c. Asian Development Bank Asian bonds online: accessed 26 December 2008. Figure for 2008 is at the end of September 2008.

d. Thorsten Beck, Asli Demirgüç-Kunt and Ross Levine, "A New Database on Financial Development and Structure", World Bank Economic Review 14 (2000): 597-605. Data updated to November 2008.

e. Balance in pension fund from World Bank, Vietnam Development Report 2008: Social Protection, Joint Donor Report to the Vietnam Consultative Group Meeting, Hanoi, December 6-7, 2007.

f. Estimated figures for 2008 from World Bank, Vietnam Development Report 2009: Capital Matters, World Bank Report to the Vietnam Consultative Group Meeting, Hanoi, December 4-5, 2008. 
Despite the prominence of banks in the formal markets, their penetration rate within the Vietnamese population is estimated to be only about 10 per cent (IFC 2008). Therefore, informal finance, with its comparative advantage in solving the inherent information asymmetry problems, obviously plays an important role in Vietnamese households and businesses, particularly in the rural areas. For the purposes of this paper, however, informal financial markets will be considered only in so far as developments in the formal markets have an impact on them. As for the formal markets, it will be seen that regulatory prejudices and the inability to address asymmetric information problems have resulted, either directly or indirectly, in discriminatory access to finance in favour of state-owned enterprises (SOEs), with adverse implications both for the development of the domestic private sector and macroeconomic stability.

\section{II.1 Recent Developments of the Banking Sector in Vietnam}

Vietnam's banking sector comprises four major and one minor state-owned commercial banks
(SOCBs), thirty-seven joint stock banks (JSBs), thirty-seven foreign bank branches, six joint venture banks, and two development and policy banks. ${ }^{1}$

As shown in Table 2, the SOCBs still hold over half of the banking sector assets both in terms of loans and deposits, although that market share has fallen from about 80 per cent of deposits and 74 per cent of loans as at 2002. Historically, the SOEs borrowed almost entirely from SOCBs so that coming out of the Asian financial crisis at the turn of the millennium, the SOCBs were heavily laden with non-performing loans (NPLs) of the SOEs. Although formally policy lending from SOCBs to SOEs has ceased, and various measures have been taken to reduce the stock of NPLs and to recapitalize the SOCBs, certain regulations (supposedly for prudential purposes) still mean that SOCBs would continue to discriminate against borrowings from the private sector in favour of SOEs. For instance, SOCBs are allowed to provide unsecured lending to private enterprises, but only to firms with at least two consecutive years of profits. Therefore, unsecured lending is not available to start-up businesses. Furthermore, the difficulties with accessing land-

TABLE 2

Banking Sector in Vietnam

(Percentage of banking sector markets)

\begin{tabular}{lccccccccc}
\hline & 2000 & 2001 & 2002 & 2003 & 2004 & 2005 & 2006 & 2007 & 6 Mos 2008 \\
\hline $\begin{array}{l}\text { Deposit market share } \\
\quad \text { SOCBs }\end{array}$ & 78.4 & 80.8 & 80.5 & 79.5 & 78.1 & 78.6 & 70.0 & 58.0 & NA \\
$\quad$ JSBs & 11.3 & 9.2 & 10.1 & 11.2 & 13.2 & 14.3 & 22.0 & 29.0 & NA \\
$\quad \begin{array}{l}\text { Foreign bank branches and } \\
\text { joint venture banks }\end{array}$ & 10.3 & 10.0 & 9.4 & 9.3 & 9.7 & 7.1 & 8.0 & 13.0 & NA \\
$\begin{array}{l}\text { Lending market share } \\
\begin{array}{l}\text { SOCBs } \\
\text { JSBs }\end{array}\end{array}$ & 72 & 73 & 74 & 73 & 75 & 68 & 63 & 54 & 50 \\
$\begin{array}{l}\text { Foreign bank branches and } \\
\text { joint venture banks }\end{array}$ & 11 & 13 & 15 & 15 & 14 & 16 & 27 & 38 & 50 \\
\hline
\end{tabular}

SourcE: Data from 2000 to 2005: Vina Capital Banking report August 2006.

Data from 2006 to 2007: IFC, Vietnam Financial Sector Diagnostic 2008.

Data for 2008: World Bank, Vietnam Development Report 2009: Capital Matters, World Bank Report to the Vietnam Consultative Group Meeting, Hanoi, December 4-5, 2008. 
use rights in urban areas make it difficult for private businesses to use land as collateral. Finally, assets of SOCBs are state assets, and any loss of state assets is still considered a capital offence. Therefore, it is not surprising that loan officers in SOCBs would err on the side of excessive caution in lending to the private sector for fear of potential losses to the state-owned bank which is a government entity.

For both 2006 and 2007, the average rate of return on assets for three of the four major SOCBs were below the average for Asian banks, and their capital adequacy ratios, although meeting the international requirements of 8 per cent, are below the regional averages of 13.1 per cent for Asia and the Pacific, and 12.3 per cent for East Asia (IFC 2008). All four SOCBs seem to have similar business strategies, and the lack of movements in lending and deposit rates even after interest rate deregulation in the period 1996 to 2002 suggest a lack of competition amongst the SOCBs (Kovsted et al. 2005). As noted above, the market shares of the SOCBs have fallen in 2006 and 2007, partly due to these banks' being required to clean up their balance sheets for equitization. Their market shares have been taken up by the JSBs.

In theory, this should be good news for the private sector as traditionally, JSBs have lent mainly to private businesses and households. In practice, however, the lax regulatory environment over the JSBs has both increased the systemic risks of the banking sector as well as provided another channel through which capital is funnelled to the SOEs. Firstly, lax regulatory environment meant that the State Bank licensed, inter alia, eleven rural credit institutions as banks in urban areas where demand for credit was mushrooming. This resulted in credit growth amongst the JSBs reaching almost 95 per cent in 2007, with significant portions of loans going into speculative activities in the then booming real estate and stock markets instead of going into productive investments. ${ }^{2}$ The stabilization measures taken in mid-2008 tightened bank liquidity, raising deposit interest rates. At the same time, the regulatory cap on lending rates meant that bank profits were squeezed (World Bank 2008b). Furthermore, the subsequent fall in the stock market index by some 60 per cent and house prices by around 50 per cent means that there will be significant increases in NPLs in the joint stock banks as mortgages get renewed. Reliable estimates on NPLs in banks are still difficult to get, despite Article 7 of State Bank Decision 493 taken in 2005 giving banks three years in which to set up their credit classification system to allow for the calculation of NPLs and loan provisioning that is closer to the international financial reporting standard. By end-2008, only two out of over eighty commercial banks have completed this process. In addition, the global economic downturn would add considerable strain to the smaller JSBs a number of which would not meet the stipulated capital adequacy ratio. Mergers with larger banks are anticipated, although monetary easing towards end-2008 seemed to have restored adequate liquidity into the banking system. No imminent banking crisis is expected, but the sector is considerably weakened.

Secondly, part of the rapid growth of the JSBs entails their equity holdings by large non-financial SOEs wishing to improve their short-term profitability by expanding into the financial sector. Although the government has restricted equity holdings by any single enterprise group in JSBs to under 30 per cent, this does not preclude "de facto" control. Nor is the State Bank likely to be able to refuse new banking licences to many of the fifteen applications from large SOEs. ${ }^{3}$ Indeed, three of those have been issued during the course of 2008. ${ }^{4}$ Experience of many countries (including Japan, Chile, and Indonesia) has shown that the formation of this type of conglomerates results in credit being channelled to companies within their business group, often with little concern about the riskiness of the loans for the depositors. This would create yet another means for capital to be channelled to the SOEs via the banks (the JSBs in addition to the SOCBs), to the detriment of the private sector and indeed the potential stability of the banking system.

Foreign bank branches have been permitted to take dong deposits in recent years, and they have gained market shares also at the expense of the SOCBs. The greatest competition for the SOCBs 
is likely to come from the three foreign banks (HSBC, Standard and Chartered, and ANZ) setting up 100 per cent-owned subsidiaries in Vietnam. ${ }^{5}$ This may also hasten the equitization and partial sale of SOCBs to strategic investors - a process that seemed to have stalled in recent months. Prices in the initial public offerings (IPOs) valued when the share market was still booming could no longer attract strategic investors after the plunge in the market.

\section{II.2 Equities Markets}

Vietnam has two regulated stock markets (one in Hanoi and one in Ho Chi Minh City), in addition to an unregulated market. Table 1 shows the very rapid growth of the regulated market in recent years (even after accounting for the bubble in 2006/2007), although share capitalization as a percentage of GDP (at 15 per cent) in Vietnam is still quite a way behind other countries in the region. ${ }^{6}$ The enactment of the Securities Law in January 2007, together with the revamp of the Investment Law 2005 and the Enterprises Law 2005, provides the legal framework, at least in theory, for the supervision of the equities markets. Under the Securities Law, the State Securities Commission (SSC) within the Ministry of Finance is responsible for the regulation and supervision of the two regulated stock markets in Hanoi and Ho Chi Minh City, the central securities depository, securities companies, securities investment fund

FIGURE 2

Breakdown of Capital Flows into Vietnam

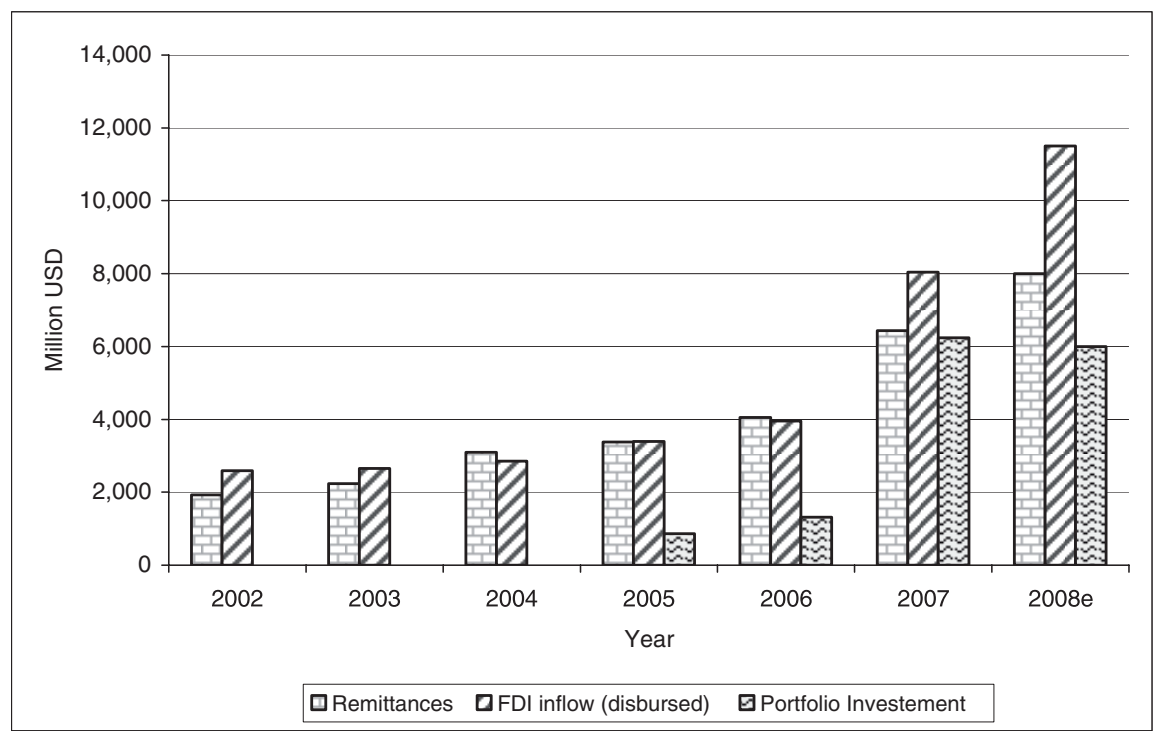

SourCES: 2002-2007 remittance and portfolio data from World Bank. Vietnam Development Report 2009: Capital Matters, World Bank Report to the Vietnam Consultative Group Meeting, Hanoi, December 4-5, 2008.

2002-2007 FDI inflow data from GSO, Available at <http://www.gso.gov.vn>, accessed 28 December 2008.

Data for 2008 portfolio investment are from Reuter, data updated to November 2008, <http://www.fxstreet.com/news/ forex-news/article. aspx?StoryId=afb34c56-7902-4188-b935-513b614b5d3b $>$.

Estimated data for 2008 FDI and remittances are from Reuter, data updated to December 2008, <http://www. fxstreet.com/news/forex-news/article.aspx?StoryId=7609b5c1-1012-4599-b075-59b3e903281b>. 
management companies, and public companies (IFC 2007). However, as with a number of other commercial laws in Vietnam (for example, virtually no bankruptcy cases fifteen years after the enactment of the Bankruptcy Law), the effectiveness of enforcement in practice, of the Securities Law and the operation of the associated courts and judiciary remains to be seen.

What has been observed throughout 2007 is the highly speculative nature of the stock market. As at January 2007, the average $\mathrm{P} / \mathrm{E}$ ratio for the twenty firms that made up the bulk of the market capitalization at the time was around seventythree, compared with average $\mathrm{P} / \mathrm{E}$ ratios in other Southeast Asian markets of between 10 and 20 (IFC 2007). With significant inflows of portfolio investment throughout 2007, the stock markets were also driven by foreign sentiments buoyed by the optimism associated with Vietnam's entry into the WTO (see Figure 2). Transparency and disclosure of the listed companies were very low whilst administrative measures (ceilings on bank lending to finance the purchase of shares, embargo on bank financing of their affiliated securitiestrading firms) were imposed in an attempt to shield the banking sector from over-exposure to an overheated market. For longer-term market development, efforts to address the asymmetric information problem through disclosures and better corporate governance would be needed. This means making the Securities Law and the associated public institutions work in the context of the Vietnamese society. Otherwise, Vietnam's equities markets will remain in the nature of gambling casinos rather than a genuine source of capital raisings for its domestic private sector.

\section{II.3 Debt Markets}

The bond market in Vietnam (as measured by the ratio of outstanding bonds to GDP) doubled from about 7 per cent of GDP in 2003 to about 15 per cent in 2008 (see Table 1). However, the market is quite small compared with an East Asian average of around 63 per cent of GDP (World Bank 2008a). Significant weaknesses in debt management, resulting in market fragmentation, have so far hampered the development of this important potential source of finance for the government as well as the corporate sector. Management weaknesses include the following:

- Firstly, government borrowings comprise approximately half external and half domestic debt, but there has been no single agency responsible for managing the total debt. As a result, there have been many small issues with varying maturities, making it difficult for a yield curve for government bonds to emerge.

- Secondly, there has been no coordination between government borrowing requirements and cash management. In order to utilize government cash flows more efficiently, shorter-term treasury bills (shorter than the current 364 days) would be needed, and these would have to be coordinated with the bills issued by the SBV itself.

- Thirdly, the management of private debt market is unclear. In principle, it should be possible for the government to manage private sector debt through an individual approvals process for external borrowings, but this would become very difficult to administer if capital controls were ever to be abolished. Otherwise, the market itself would have to manage private sector borrowings, but this requires stringent corporate disclosure rules, reliable credit-rating agencies, and other market infrastructure to be in place. In other words, the asymmetric information problem would need to be resolved. So far, only a handful of large SOEs have been able to issue corporate bonds as the expectation that these would be honoured by the government has so far overcome the problem of opaque information.

These problems have been recognized and are supposed to be addressed through the process of preparing for a Public Debt Law. However, resolving the above issues in practice, would require significant cooperation amongst a number of agencies, including the Ministry of Finance (MOF), the State Securities Commission, the tax department (GDT), and the State Bank (SBV). This is another instance where strengthening 
Vietnam's public institutions would be crucial for the next phase of its reform.

\section{II.4 Insurance Companies and Pension Funds}

Life insurance and pension funds tap long-term savings of households and hence provide a source of long-term finance to businesses. However, the development of these institutions in Vietnam has been hampered, in part, by the lack of good quality, high yielding, long-term investments in local currency (IFC 2008). This situation is hard to reconcile with the country's need for infrastructure capital. One reason is the lack of reputable and well-managed long-term government and corporate bonds mentioned above. Until the prudential regulatory framework succeeds in increased transparency in Vietnam's banks and listed companies, the lack of longer term investment opportunities would increase the chances of speculative short term asset price bubbles.

\section{II.5 Impact on Informal Finance}

In principle, there exist pressures for both competition and cooperation between formal and informal lenders. Formal lenders have cheaper access to funds, but they face higher monitoring costs. Informal lenders, because they have more intimate knowledge of the borrowers in their communities, have a comparative advantage in lower monitoring costs, but their cost of funds is generally higher. Therefore, to the extent that there are monopoly rents accruing to the informal lenders, the entry of the formal lenders would drive down interest rates for the borrowers. At the same time, in order to maximize profits, the formal lenders might make use of the lower monitoring costs of the informal lenders, and lend to the latter who would then on-lend to the final borrowers. This would seem to be welfareenhancing as the final borrowers could benefit from both the lower costs of funds of the formal lenders and the lower monitoring/transactions costs of the informal sub-market (Ghate 1992).

In the case of Vietnam, much of the formal submarket in competition with informal lenders takes the form of two state-owned institutions; namely, the Vietnam Bank for Agriculture and rural Development (VBARD) and the Vietnam Bank for Social Policies (VBSP). The smaller joint stock banks do not appear to be major players in this area as judged by their desire in the last two years to seek rapid growth through becoming urban banks rather than remain in rural areas.

The VBARD is a state-owned commercial bank which has a very extensive network but lends on commercial terms and requires collateral on most loans. The VBSP is exempt from many of the regulations governing state-owned commercial banks as well as those governing microfinance institutions. It was set up in 2002 specifically for policy lending, and is financed variously from the state budget, taxes on SOCB deposits, borrowings from the SBV and the State Treasury, and from the Vietnam Postal Service Savings Company which makes use of post offices around the country in order to siphon savings to policy and other lending. The VBSP lends directly to small businesses, and through the establishment of savings and credit groups, to poor households without collaterals in the microfinance model. It is assessed to be in direct competition with moneylenders, trade credit providers, and other informal microfinance lenders, as well as with VBARD (World Bank 2008a).

As the VBSP is definitely subsidized and does not work under profit-maximizing principles, there would not exist pressures to take advantage of the complementarities with informal lenders. Indeed, a review of the beneficiaries/clients of VBSP does not reveal any particular cooperation with informal lenders (World Bank 2008a). Therefore, it might be concluded that informal finance in Vietnam would have been negatively affected by the existence of the VBSP. ${ }^{7}$

This is unfortunate as increased linkages in the supply of credit between formal and informal financial sectors could help with overall monetary and stabilization policies as the latter act chiefly on the formal sector, with flow-on effect to the informal sub-markets. This would seem to assume increased importance as Vietnam enters the realm of emerging market economies where macro- 
economic turbulence stemming from financial sector instability becomes more prevalent.

\section{Macroeconomic Turbulence and Weaknesses in Financial Sector}

The laxity in prudential supervision of banks and equities market points to deep-seated problems within the key macroeconomic institutions of Vietnam; namely, the SBV and the MOF. Whilst the failure on the part of these institutions to address the asymmetric information issue within the financial sector has led to medium-term development problems such as the lack of financial access for the domestic private sector, this failure also greatly complicated short-term macroeconomic management in which the weaknesses of the SBV and MOF were only too apparent.

The macroeconomic turbulence in mid-2008 can be traced back to substantial surges in capital inflows in late 2006 and into 2007, mainly in response to the optimism engendered by Vietnam's entry into the WTO. ${ }^{8}$ These inflows took the form of foreign direct investment, portfolio flows, and remittances by Vietnamese living abroad. At the same time, the rigid maintenance of a fixed exchange rate peg to the U.S. dollar meant substantial intervention on the part of the SBV in the foreign exchange market to prevent appreciation of the dong. ${ }^{9}$ International reserves rose by US $\$ 10$ billion in one year, reaching US $\$ 21.1$ billion at end-2007 (World Bank 2008a). The SBV failed to sterilize these interventions through open market operations (or indeed through any other means). Lack of bond market development (see section II) was a contributing factor, but also the asset price bubble in the real estate and share markets meant that interest rates on government bonds were not sufficiently attractive for investors. As a result, money supply increased rapidly by March 2008. M2 grew at a rate of 45 per cent and bank credit at 63 per cent. Vietnam was caught in the classic dilemma of the "Impossibility Trinity" — the maintenance of exchange rate stability and free flow of international capital is incompatible with monetary independence.
On top of loose monetary conditions came aggressive expansion by SOEs, unchecked by the MOF. Bank borrowings by the SOEs in 2007 increased two and a half times to 10 per cent of GDP. Given that credit growth amongst the SOCBs remained unchanged at around 25 per cent during 2007, the bulk of SOE borrowings came from the JSBs where credit growth reached 95 per cent (World Bank 2008a). Therefore, a loss of control over money supply and SOE spending, compounded by failure to supervise the JSBs, resulted in significant overheating of the economy in 2008 as well as increased vulnerability of the banking sector. Inflation reached 28 per cent by July 2008, and current account deficit stood at 11.5 per cent of GDP.

Belated monetary and fiscal tightening has seen some restoration of macroeconomic stability by the fourth quarter of 2008. However, this involved using administrative measures such as ceilings on credit growth of banks, increased reserve requirements, compulsory bank purchase of treasury bills on the monetary side, and direct government limitations on SOE non-core spending on the fiscal side. Weaknesses in the institutional capacity of SBV and MOF have impeded the use of indirect or more incentive/ market based instruments. In the very short-run, administrative measures may be (and indeed, were) effective in stopping the blow-out of a financial crisis. However, as soon as the crisis shows signs of abating, the SBV would again be under pressure to license more new JSBs, ${ }^{10}$ and the MOF would be induced to broaden the definition of non-core SOE activities (for example, could the building of storage capacity by the state-owned shipping company be considered core activity?) Therefore, by hindering the development of financial markets and the bureaucratic capacity to deal effectively with market participants (including putting binding financial constraints on SOEs), administrative measures do little to prevent the recurrence of financial crises, and could in fact contribute to the boom and bust scenario. ${ }^{11}$ For this reason, it is imperative that Vietnam, in going into Doi Moi 3 (or phase 3) of its reform 
agenda, places priority on the development of institutional capacity in managing its financial markets.

\section{Building Strong Public Institutions}

Whilst building public institutions necessarily include legal development and public administration reform, this paper concentrates on development of the key macroeconomic institutions; namely, the State Bank of Vietnam and the Ministry of Finance which are primarily responsible for economic policy making and for the prudential regulation of financial and corporate sectors.

\section{IV.1 State Bank of Vietnam (SBV)}

For the SBV to function as a modern central bank, it needs to have the capacity to formulate monetary and exchange rate policies, and to be able to communicate regularly with the general public on the state of the Vietnamese economy and the stance of those policies. In addition, as is the case with many modern central banks, the SBV would also be responsible for the licensing and prudential supervision of banks to ensure the stability of the Vietnamese banking system.

Policy formulation and communication require a great deal of professional skills particularly in economics, and the SBV has begun in earnest to upgrade its staff training in Western universities. It is also planning to collect and publish in a systematic manner, the relevant economic statistics on which serious policy research is based. ${ }^{12}$ In the next few years whilst the upgrading of staff is taking place, the SBV would need to be flexible in its staffing policy, and make use of trained economists elsewhere in the bureaucracy (for instance, the CIEM within the Ministry of Planning and Investment), perhaps on a secondment basis.

Throughout the macroeconomic turbulence of 2008, the SBV has been consulting with the IMF, and has made use of technical assistance from the Fund. As the technical capacity of its professional staff improves, the SBV should be able to benefit more widely from its participation in regional and international forums of central bankers. Managing surges in capital inflows, for instance, is a lesson which many East Asian central bankers have learnt from the Asian financial crisis a decade ago.

As for prudential supervision of banks, the fundamental conflict between SBV as owner and as supervisor of the SOCBs needs to be resolved. At the very least, the SBV needs to be extricated from the board of the SOCBs, with the latter being treated like any other SOEs. Speedy equitization and sale of SOCBs to foreign strategic investors (à la China's Industrial and Commercial Bank) would help in resolving this conflict of interest. ${ }^{13}$ Even if that were to occur, however, the shares owned by the State would need to be separated from the SBV. Under current arrangements, the state-owned shares in equitized SOCBs would come under the control of the State Capital Investment Corporation (SCIC) which is a "forprofit organization mandated to exercise ownership rights in SOEs on behalf of the state" (World Bank 2008a, p. 61). How effectively the SCIC will be able to manage the state capital within the SOCBs is another issue, but at least this would, in theory, allow the SBV to act as the supervisor of the banking system without any conflict of interests.

With the entry of fully-owned subsidiaries of foreign banks into the Vietnamese market, it is important that SBV be the sole supervisor of banks in Vietnam, and be perceived as such by the supervising authorities of the foreign banks in their home countries. This is so because the SBV would need to liaise closely with other banking supervisors, as an incident involving a bank's subsidiary may result in systemic risk in the host country, but relatively minor risk in the home country. Whether the subsidiary should be rescued and by whom becomes an important issue. For this reason, the relationship between the SBV and other financial supervising authorities in Vietnam (such as the recently established National Financial Supervision Committee) would need to be clarified.

It is understood that legislation is in train to give greater independence to the SBV. Kovsted 
et al. (2005) found that indicators of legal and political independence of the SBV were comparable with other central banks in the region. However, operational independence and the ability of the SBV to take prompt corrective action are judged to be low. Like other aspects of Vietnam's commercial law, the effectiveness of implementation remains to be seen.

Implementation is often associated with professional capacity. In the case of prudential supervision of banks, highly skilled professionals in auditing and commercial risk assessment, in addition to a general understanding of economics, are needed. Furthermore, there needs to be an understanding that for regulatory bodies to work effectively, they need to be independent not just in a legal or even in a financial sense, but in the public perception that these institutions are run by people with professional integrity. There is quite a way to go in this area of government in Vietnam, but the SBV would seem to be a good place to start.

\section{IV.2 Ministry of Finance (MOF)}

Bingham and Leung (forthcoming) points out the myriads of management and accounting systems within the MOF resulting in the generation of unreliable data on which fiscal plans are made. It is not surprising therefore that there are often significant variations in planned targets and outcomes, and that Vietnam scored only two out of a possible 100 in the Open Budget Index (2006) - a survey of fiscal transparency undertaken by the International Budget Project. As Vietnam is already dependent on international capital inflows to fund its sizeable current account deficit, the lessons during the Asian financial crisis from the Ministry of Finance in South Korea are instructive.

The study by Dooley and Shin (2001) points out that a major contributing factor to the financial crisis in South Korea in 1997 was the failure on the part of the Bank of Korea to regulate the consolidated balance sheet of the Korean banks (taking into account the foreign currency deposits in their overseas bank branches). As a result, there were gross under-estimates of Korea's external debt position on the part of their ministry of finance. As these estimates were being revised upwards throughout December 1997, Moody's and Standard \& Poor downgraded South Korea's sovereign credit rating three times in one month, badly affecting investor confidence, and the banking and currency crisis worsened considerably for South Korea within the month. For Vietnam to continue with globalization of its financial markets in a stable manner, the reform of MOF's internal management and systems would seem to be a priority.

Weaknesses in the development of the bond market are noted in section II above. The government is apparently giving attention to the issuance and auctioning of government bonds in order to provide the primary market with a yield curve. Technical assistance is being utilized to help the MOF in furthering the development of the government bond market.

The highly speculative nature of the Vietnamese stock markets indicates that the regulatory functions of the State Securities Commission (SSC) within the MOF need to be strengthened. It is questionable whether Vietnam actually needs two stock exchanges. Indeed, it may be desirable for Vietnamese firms to be encouraged to list with regional exchanges in Hong Kong and Singapore where much higher standards of corporate governance and transparency are enforced.

\section{Conclusions}

The world financial and economic crisis of 2008/ 09 demonstrates clearly the importance for central banks and ministries of finance to react promptly and flexibly to rapid changes in the global economy, as well as to improve their ability to manage the information asymmetry problems in their supervision of the financial sector. Vietnam's key macroeconomic institutions are quite a way from "best practice" both in terms of professional capability and operational independence.

High-quality training programmes are being put in place for staff of the SBV, and numerous 
scholarships for study in reputable universities worldwide are available for the staff of Vietnamese government bureaucracies including the MOF. Experience of staff training in other parts of the bureaucracy (for instance, in the CIEM of the Ministry of Planning and Investment) has shown that Vietnamese young people are highly adept at economics, finance, and business studies. However, the effectiveness of their training is significantly improved if, upon their return to the home institutions, they are able to work for a time in a team led by an experienced economist - often someone who has had considerable experience in a central bank or ministry of finance of an OECD country or an international financial institution. Some of this is already occurring as part of technical assistance from bilateral and multilateral agencies, but the various initiatives need to be coordinated and commitments from senior management of the SBV and MOF need to be secured. With the macroeconomic turbulence fresh in their minds, senior management is open to new ideas and is likely to commit to serious staff training initiatives.

Furthermore, in terms of macroeconomic research and policy formulation, the numbers of highly qualified staff needed are relatively small; hence the actual organization and management of research teams should not be onerous. Although prudential supervision of financial institutions is necessarily more labour-intensive, the actual numbers of skilled personnel required should still be manageable, provided they are supported adequately by workable IT systems. Again, technical assistance from various aid agencies is proceeding at a rapid pace. In short, the enhancement of professional capability in Vietnam's key macroeconomic institutions, although challenging in the short run, could be achieved in a five to ten year perspective. Meanwhile, as mentioned before, the SBV and MOF should consider utilizing existing talent elsewhere in the bureaucracy, perhaps on a secondment basis.

Within ASEAN, substantial reform of the central bank of the Philippines, the BSP, took place within a relatively short space of time in 1991. The BSP has demonstrated that an effective and professionally respected institution can be set up in the midst of a generally disorganized and corrupt bureaucracy. This example was later emulated by Bank Indonesia (Hill forthcoming). This is indeed an erstwhile lesson for the leadership of Vietnam. The style of consensus decision-making in Vietnam has been observed to involve conducting small controlled experiments within the country, to be appraised by various sections of the leadership before applying the changes more generally throughout the economy (Rama 2008). In the case of macroeconomic reforms, however, the more feasible option might be to observe the experience of other countries, particularly within the ASEAN plus three grouping, and then applying it to the Vietnamese context. The myriads of study tours from Vietnamese officials and ministers to countries in the region, although time-consuming from the point of view of the government agencies in the host countries being visited, may in fact contribute to building up consensus within the Vietnamese government for reforms of their public institutions.

Delays in the equitization and sale of the large SOEs (the so-called General Corporations) have been rationalized by the pretext that size matters in world competition, and that Vietnam needs these large SOEs to help it compete in the post-WTO world. Until the outbreak of macroeconomic turbulence in mid-2008, the operations of these large SOEs turned conglomerates had been condoned under the slogan of a "market economy with socialist orientation". Since then, the spotlight has been shone on the role played by these conglomerates in overheating the economy, funded by bank finance and government foreign borrowings. It is becoming increasingly clear that not only are the activities of these General Corporations adding to the non-performing loans of the banking system, they have actually been a factor in destabilizing the macroeconomy. Therefore, despite continuation of state ownership and/or control in these large corporations, the argument that these corporations should no longer 
be subsidized in the capital market may be gaining some political attention. This move would certainly be supported by the new foreign banks which are entering the Vietnamese market on very competitive terms. Enhancing the licensing and supervisory role of the SBV would further level the playing field in terms of access to capital between the large SOEs and the domestic private sector. Pessimists argue that the powers of the large SOEs are too strong, and the level of corruption within the upper echelons of government too entrenched for any effective powers to be given to the SBV and the MOF. On the other hand, recent economic problems in Vietnam, not to mention recession in the global economy, have demonstrated the dependence of the one party rule on the continuation of stable economic growth in order to meet the rising expectations of the populace. As Vietnam reaches the emerging market economy status, the leadership may have little choice other than to depend on the professionalism of its key macroeconomic institutions to steer the economy through periods of financial turbulence.

\section{NOTES}

1. Eighty-seven banks seem to be a disproportionately large number for a population of 86 million compared with, for example, 216 banks in China (excluding rural financial institutions) servicing a very much larger population.

2. Towards end 2007, fearing a burst of the stock market bubble, the government put a cap of 3 per cent of bank lending to purchase of securities. This cap was later converted to 20 per cent of a bank's chartered capital.

3. Fifteen as at start of 2008. Several licences have been granted since then (see note 4 below).

4. These comprise the FPT Bank (earlier known as the Tien Phong Bank) with large stakes held by the Corporation for Financing and Promoting Technologies, Mobiphone, and the State Capital Investment Corporation; the Lien Viet Bank owned mainly by the Him Lam Ltd, the Saigon Trading Group, and the Southern Airport Services Company (a SOE); and the most recently established Bao Viet Bank which is controlled by the state-owned insurance company.

5. Two more 100 per cent owned subsidiaries of foreign banks (from the Asian region) have been announced in recent weeks, making a total currently of five wholly-owned foreign subsidiaries in the market.

6. At the end of 2006, stock market capitalizations as a percentage of GDP were 288 per cent for Singapore, 68 per cent for Thailand, 57 per cent for the Philippines, and 44 per cent for China.

7. Experiences in Thailand, the Philippines and Sri Lanka have shown that the impact of government subsidized banks result in a shrinkage of informal finance both in the provision of loans to poor households and to small businesses (Armendariz and Morduch 2007). Indeed, given the substantial relationship between the VBSP on the one hand and the mass organizations (e.g., workers unions, women's union) and local government authorities on the other, it might be a reasonable conjecture that state subsidy is being used to enhance political control and influence in the rural areas as well as, of course, to alleviate poverty.

8. These inflows were in excess of 20 per cent of GDP.

9. Instead of appreciation, the dong actually depreciated by 0.14 per cent against the dollar in 2007 .

10. See notes 3 and 4 above.

11. For instance, when the dong was under pressure to be devalued in June 2008, the SBV banned third currency trading by commercial banks (the so-called "grey market") in an effort to curb arbitrage and enforce the official exchange rate. The move incited fears that the SBV might be left as the only legal supplier of foreign exchange, and had to use the country's international reserves to back what was perceived to be an over-valued exchange rate. Luckily, the market did not, at that instance, decide to bet against the SBV, but high-risk strategies like these could easily bring about surges in capital outflows à la Thai style in 1997.

12. Author's interviews with senior SBV staff, 10-11 November 2008.

13. The Industrial and Commercial Bank of China (ICBC) sold a 10 per cent stake to foreign strategic investors at a price equal only to around 25-30 per cent of the then market price. Within one year, the contribution of the strategic investor was such that the share price of the ICBC more than doubled, benefiting both the state owner and other investors. This is in contrast to the recent attempt at equitizing the Vietcombank where the IPOs to foreign investors were priced at unrealistically high levels (Fulbright Policy Discussion Paper No. 2). 


\section{REFERENCES}

Armendáriz de Aghion, B. and J. Morduch. The Economics of Microfinance. Cambridge, MA: MIT Press, 2007.

Bingham, B. and S.E. Leung. "Vietnam Country Case Study". In Globalization and Economic Development in Mekong Economies, edited by B. Bingham, M. Davies, and S.E. Leung. U.K.: Edward Elgar, forthcoming.

Dollar, D. and J. Litvack. "Macroeconomic Performance and Poverty Reduction". In Household Welfare and Vietnam's Transition to a Market Economy, edited by D. Dollar, P. Glewwe and J.I. Litvack, pp. 1-26. World Bank, 1998.

Dooley, M.P. and I. Shin. "Private Inflows when Crises Are Anticipated: A Case Study of Korea". In Financial Crises in Emerging Markets, edited by R. Glick, R. Moreno and M.M. Spiegel. Cambridge: Cambridge University Press, 2001.

Fulbright Policy Discussion Paper no. 2. Surviving a Crisis, Returning to Reform, Kennedy School of Government, Harvard University, MA, 2008.

Ghate, P. Informal Finance: Some Findings from Asia. Hong Kong: Oxford University Press, 1992.

Hill, H. "Political Economy of Economic Reform". In Globalization and Economic Development in Mekong Economies, edited by Davies Bingham and S.E. Leung. U.K.: Edward Elgar, forthcoming.

IFC (International Finance Corporation). Vietnam: Capital Market Review, 2007.

- Vietnam: Capital Market Diagnostic Review, 2008.

Kovsted, J., J. Rand, and F. Tarp. From Monobank to Commercial Banking: Financial Sector Reforms in Vietnam. Copenhagen: Nordic Institute of Asian Studies, 2005.

Leung, S.E. "Integration and Transition — Vietnam, Cambodia and Lao PDR". In Sustaining Development and Growth in East Asia, edited by Timo Henckel. Routledge, forthcoming.

Leung, S.E. and V.T. Thanh. "Vietnam in the 1980s: Price Reform and Stabilization". Banca Nazionale Del Lavoro 197 (1996): 187-208.

Rama, M. "Making Difficult Choices: Vietnam in Transition". Commission on Growth and Development Working Paper no. 40, Hanoi, 2008.

Reinhart, C.M. and V.R. Reinhart. "Capital Flow Bonanzas: An Encompassing View of the Past and Present". Working Paper No. 14321, National Bureau of Economic Research Working Paper Series, 2008.

Riedel, J. "Needed: A Strategic Vision for Setting Reform Priorities in Vietnam". In Vietnam and the East Asian Crisis, edited by S.E. Leung. U.K.: Edward Elgar, 1999.

World Bank. Banking Sector Review: Vietnam June 2002. Hanoi: World Bank, 2002.

- Vietnam Development Report 2009: Capital Matters, World Bank Report to the Vietnam Consultative Group Meeting, December 4-5, 2008. Hanoi: World Bank, 2008 .

- Taking Stock: An Update on Vietnam's Recent Economic Developments, World Bank Report to the Annual Consultative Group Meeting fro Vietnam, December 4-5, 2008: Hanoi: World Bank, $2008 b$.

Suiwah Leung is Associate Professor of Economics and Convenor of the Vietnam economic and public policy program at the Australian National University. 
Reproduced with permission of the copyright owner. Further reproduction prohibited without permission. 